\title{
Whether Android-Based Learning Media Actually Improve Learning Outcomes?
}

\section{Development of Digital-Based Teaching Materials in the Covid-19}

Era

\author{
Buyung Adi Dharma ${ }^{*}$, Mia Novita Santi ${ }^{2}$, Lulu Nurul Istanti ${ }^{3}$, Madziatul \\ Churiyah $^{4}$
}

1,2,3,4 Universitas Negeri Malang, Malang, Indonesia

*Corresponding author. Email: buyung.adi.fe@um.ac.id

\begin{abstract}
The purposes of this research and development are: (1) Create android-based learning media use the MIT Inventor App to improve learning outcomes in general administration subjects, (2) Know the feasibility of learning media developed through validation results by material experts and media experts as well as small group trials, and (3) Knowing the differences from learning outcomes of students, who use and do not use developed learning media. This research uses borg and gall research and development models that are modified into 8 steps, namely: (1) Initial research and information collection, (2) Planning, (3) Product Development, (4) Expert validation, (5) Product Revision, (6) Small group trials, (7) Product revisions, and (8) Large group trials. The overall validation result is $90.52 \%$ on average with the criteria very feasible to use. While the results of the Independent Sample t-Test test on this research shows that there are differences in the learning outcomes of students using learning media developed with the learning results of students who do not use developed learning media, it can be concluded that android-based learning media using MIT Inventor App can improve the learning outcomes of students in general administration subjects.
\end{abstract}

Keywords: Learning media, Android, MIT inventor app, Learning outcomes, General administration.

\section{INTRODUCTION}

Technology in the era of globalization as it is today is growing very quickly and thoroughly in all circles and fields. One area that can't be separated from technology in education. Education has an important position to play in human resources quality preparations and being able to compete in development. Educational institutions are required to be adaptive to the paradigm shift of education from traditional to information technology which is the demand of the global community [1]. By utilizing Information and Communication Technology (ICT), the effectiveness and efficiency of education can be improved [2]. Fast development of science and technology today demands to participate in the use of technology as a form of innovation in learning [3]. The formation of learning innovation that utilizes the Information and Communication Technology (ICT) development purpose to develop learning devices and media. The proper use of media will make the attractiveness of students in learning even higher. The use of android can also support the learning independence of students. Selfreliance is defined as the nature of the ability of students to conduct proactive learning activities, which are drive a motive to master a competency, and built the knowledge or competence they [1].

Based on observations made by researchers at SMK Negeri 1 Lumajang obtained the results that in the implementation of teacher learning usually use package books and whiteboard media as a learning medium in the classroom. Teachers have not maximized technology use as supporting material for learning in the class, while the demand for education in this era of technology is the utilization of technology in supporting learning activities. Teachers are required to be information literacy, media literate, and information technology (IT) literacy. Computers and mobile phones should have become the daily life of teachers in teaching in the classroom. By keeping up with the progress of 
technology, teachers will be able to provide more advanced perspectives, alternatives, and solutions to students. Based on the above problems, to meet the current educational demands, there needs to be an innovation in learning. One form of innovation is to use media that can increase the learning independence of students so that they achieve good learning goals [4]. Therefore, researchers want to create an android-based learning media using the MIT Inventor App that will be used in general administration subjects.

Some of the previous studies that are in line with this study conducted by Amsha \& Omari [3] titled "Quizrevisions: A Mobile App Applications using Google MIT App Inventor Language Compared with $L M S$ ", produce quiz-shaped learning media that supports the achievement of students and increases the involvement of learners in the use of learning media. In addition, research conducted by Nugroho [3] entitled "The Making of Mobile Learning as Learning Media Using MIT App Inventor 2 in Alternative Energy Course", produced mobile-learning based learning media that can be used in the learning activity and at the time of the trial the media received an excellent response from students.

\section{METHOD}

This research uses the sort of research and development of R\&D (Research and Development). Development research may be a process or steps to develop a replacement product or improve an existing product, which may be accounted for [5]. The product mentioned during this development research is androidbased learning media using the MIT Inventor App. The research and development model employed by researchers is that the [6] 10-step development model with the following steps: 1) Research and knowledge , (2) Planning, (3) Develop Preliminary sort of Product, (4) Preliminary Field Testing, (5) Main Product Testing, (6) Main Field Testing, (7) Operational Product Testing, (8) Operational Field Testing, (9) Final Product Revision, and (10) Dissemination and Implementation .

This research and development procedure of learning media was modified from the Borg and Gall model which had been simplified from 10 steps to 8 stages to be adapted to the circumstances in the field, time constraints, energy, and cost. Here are the steps that researchers have simplified, "(1) Preliminary Information Collection, (2) Planning, (3) Early Product Format Development, (4) Initial Product Trial, (5) Revised Initial Product Trial Results, (6) Small Group Trials, (7) Small Group Trial Product Revisions, and (8) Field Trials".

This stage is carried out with the aim of determining the level of feasibility of the resulting product. The sequences in this stage are trial design, test subject, data type, data collection instrument, and data analysis.

The trial design aims to get complete data so that it can be used to improve media and know the feasibility of the resulting product. This stage consists of two stages, namely expert trials as well as trials on students in class $X$ OTKP SMK Negeri 1 Lumajang.

The test subjects in this research and development consisted of 3 groups, namely (1) Expert or expert trials consisting of media experts who are lecturers of Education Technology faculty of Education, Malang State University and material experts namely general administration subjects teacher class X OTKP at SMK Negeri 1 Lumajang, (2) Small group trials consisting of 6 students with criteria of 2 highly skilled students, 2 moderate-skilled students, and 2 under-skilled students drawn from class X OTKP 2, and (3) Field trials consisted of students from SMK Negeri 1 Lumajang Automation and Office Governance Skills Program Class X consisting of 34 students and a control class of 36 students.

This research and development type of data is qualitative and quantitative data. Qualitative data is obtained from observations and initial interviews conducted by researchers as well as criticisms, suggestions, and responses provided by validators and the use of small groups. While quantitative data is obtained from the results of polls shared with media experts, material experts, and the use of small groups.

This research and development used data collection instruments in the form of interviews, observations, questionnaires, tests, and documentation. The results of interviews and observations in the form of notes from activities in the field, namely in SMK Negeri 1 Lumajang. While the questionnaire is used to collectsdata from the evaluation of experts (material and media experts) and users (students class X OTKP 2 SMK Negeri 1 Lumajang). The use of this questionnaire is used to determine the extent to which students can receive android-based learning media using the MIT Inventor App as a developed learning medium as well as to measure the feasibility of those media. In addition, tests are used to obtain data on students' learning outcomes after using developed learning media, as well as documentation containing photographs during the research process.

The data analyzed during this research and development consists of qualitative data and quantitative data. Qualitative data is employed to research criticisms, suggestions, and opinions from media experts, materials experts, and learners. While quantitative data is used to process data obtained from questionnaires in the form of descriptive presents then underachieved with qualitative sentences.

Validity tests during this study were wont to measure whether learning media would be developed by researchers. Validity tests in this study are used for media experts, materials experts, and users. To calculate the percentage of the overall score is used formula according to [7] as follows:

$\begin{aligned} V_{x} a h & =\frac{\text { Tse }}{\text { Tsh }} \times 100 \% \\ V_{x} p g & =\frac{\text { Tse }}{\text { Tsh }} \times 100 \%\end{aligned}$ 
Description:

V.ah: Expert Validation

V.pg: User Validation

Tse: Number of Answers Scored

Tsh: Number of Answers Maximum Score Scoring 100\%: Constants

After presenting, the next step is to describe and draw conclusions about the development of learning media using the following table:

Table 1. Presents Evaluation of Test Subjects

\begin{tabular}{|c|c|c|l|}
\hline № & $\begin{array}{c}\text { Value } \\
\text { Achievement } \\
\text { Criteria } \\
\text { (Effectiveness) }\end{array}$ & $\begin{array}{c}\text { Effectiveness/ } \\
\text { Validity }\end{array}$ & \multicolumn{1}{|c|}{ Description } \\
\hline 1 & $81,00-100,00$ & Very Valid & $\begin{array}{l}\text { Can be used } \\
\text { without revision }\end{array}$ \\
\hline 2 & $61,00-80,00$ & Valid & $\begin{array}{l}\text { Works with minor } \\
\text { revisions }\end{array}$ \\
\hline 3 & $41,00-60,00$ & Less Valid & $\begin{array}{l}\text { Recommended not } \\
\text { to use as it needs } \\
\text { major revisions }\end{array}$ \\
\hline 4 & $21,00-40,00$ & Invalid & Cannot be used \\
\hline 5 & $00,00-20,00$ & Very Invalid & Cannot be used \\
\hline
\end{tabular}

Source: Akbar, 2016 with modifications

The next stage performed by the researchers is to analyze the learning results of the students. The results of this study are the results of learning the realm of cognitive and psychomotor. The results of the assessment were then analyzed using the Independent Sample t-Test with the help of the SPSS 24.0 for Windows program. Before the test is done, there are several preliminary tests that must be done namely Normality Test, Homogeneity Test, and Independent Sample t-Test.

The normality test stage is performed to see if the research data is distributed normally or not. Normally distributed data is one of the requirements in the use of parametric statistics. The formula used in this normality test is Kolmogrov Smirnov Test using the SPSS 24.0 for Windows program provided that if the significance value (sig) $>$ is 0.05 then the data is a normal distribution. Meanwhile, if the significance value $($ sig) $<$ is 0.05 then the distributed data is not normal

The homogeneity test aims to find out whether variations of some data from the population have the same variance or not. This test generally serves as a condition (although not an absolute requirement) in comparative analysis such as the Independent Sample tTesttest. According to [7] basic or decision-making guidelines in homogeneity test that is, if the value of significance or Sig. $<0.05$, it is said that the variance of two or more data group population data is not the same (not homogeneous). Whereas if the value of significance or Sig. $>0.05$, it is said that the variance of the two or more data population groups data is the same (homogeneous).

If at the normality test stage it's known that the info is distributed normally, subsequent step is to perform a t- test to seek out out the difference within the results of the experiment class learning (which uses android-based learning media using the MIT Inventor App) and control classes (which don't use android-based learning media using the MIT Inventor App using point media). The Independent Sample t-Test is conducted through the SPSS 24.0 for Windows program as long as if the importance value (sig 2 tailed) $>0.05$ is accepted and rejected, which suggests there's no difference in learning outcomes between the experiment class and therefore the control class. Whereas if the worth of significance(sig 2 tailed) $<0.05$ is rejected and accepted, which suggests there's a difference in learning outcomes between the experiment class and therefore the control class.

\section{RESULTS AND DISCUSSION}

The results of this research and development study is android-based learning media using the MIT Inventor App on General Administration Subjects Class X Of The Automation and Office Governance Skills Program Semester 2. Research uses Research and Development (R\&D) methods with research and development procedures adapted from the event model suggests by [8] The model developed was modified by researchers to suit environmental conditions, time constraints, power limitations, and costs. Thus during this study researchers took eight steps that included: (1) Preliminary Information Collection, (2) Planning, (3) Early Product Format Development, (4) Initial Product Trial, (5) Revised Initial Product Trial Results, (6) Small Group Trial, (7) Product Revision of Small Group Trial Results, and (8) Field Execution Test.

Validation data on this study was obtained from material experts, media experts, and 6 students in small group trials. The overall validation data results as in Table 2 below:

Table 2 Overall Validation Result Data

\begin{tabular}{|c|l|c|c|}
\hline № & \multicolumn{1}{|c|}{ Validator } & Percentage & $\begin{array}{c}\text { Eligibility } \\
\text { Criteria }\end{array}$ \\
\hline 1 & $\begin{array}{l}\text { Material } \\
\text { Expert }\end{array}$ & $89,41 \%$ & Very Decent \\
\hline 2 & Media Experts & $95,29 \%$ & Very Decent \\
\hline 3 & Learners & $86,87 \%$ & Very Decent \\
\hline \multicolumn{2}{|r}{} & $\mathbf{9 0 . 5 2 \%}$ & Very Decent \\
\hline
\end{tabular}

Source: Material Expert Validation Data, Media Experts, and Small Group Trials, 2020

Based on the results of the general validation data are often concluded that android-based learning media using the MIT Inventor App is extremely feasible and may be used as a learning medium

Results from the Kolmogrov-smirnov normality test showed that the results of the experiment class pretestposttest and control class pretest-posttest scores had their respective significance scores - each an experimental grade pretest score of 0.164 , the experiment class posttest value is 0.119 , the control class pretest value is 0.136 , and the control class 
posttest value is 0.200 , where all values of that significance are $>0.05$ so it can be concluded that the value of the pretest and posttest questions is normal.

Meanwhile, homogenity test results for experiment class pretest results and control classes show that the Sig value is $0.997>0.05$ and therefore the Sig value for posttest results is $0.280>0.05$. From the results of the homogeneity test, it are often concluded that the experiment class and control class have the same or homogeneous data variants and both classes are deserve comparison or testing because they need an equivalent starting position.

The Independent Sample t-Test during this study was conducted to check differences in experiment grade results (using android-based learning media) and control class grade results (which don't use android-based learning media). Based on the independent sample t-test leads to the Equal Variances Asummed section known sig value. ( 2 tailed) $0.008<0.05$, it are often concluded that there's a big (noticeable) difference between the typical results of the study of the experiment class students and therefore the control class students. As for showing the difference in average score results - the typical between the experiment class and therefore the control class used descriptive analasis with the result that's the typical or mean score for the experiment class posttest is 83.02 while for the control class posttest is 80.50 with a mean difference of two .52 . additionally, the difference in average grades for experimental classes using android-based learning media using the Mit Inventor App was 7.05 points while the control class that didn't use android-based learning media using the Mit Inventor App only increased by 5.36 points. So it are often concluded that android-based learning media using the MIT Inventor App is more effectively utilized in the training process because it can further improve the training outcomes of scholars .

The final product of this research and development is android-based learning media using the MIT Inventor App. The resulting product contains general administration material for The Automation and Office Governance Skills Program class X SMK Negeri 1 Lumajang. This learning medium are often operated through all types of android smarthphones. There are several advantages during this developed learning medium. First, the media evokes the motivation and stimulation of learning activities, and even carries psychological influences on students [9]. Therefore, researchers created android-based learning media using the MIT Inventor App together of the supporting students in generating students' learning interests.

Second, android-based learning media using mit inventor app is flesibel and practical [10]. This media allows students to learn materials without limited time, meaning that students can learn outside of learning hours, so that it will have a positive impact for students that allows the oning of self-study [11]. In addition, using the android base allows easy access to content and provides students with opportunities to study outside the classroom and allows students to learn anywhere, anytime via mobile phone or smartphone to facilitate the exchange of information between teachers and students [3].

Third, the developinbg of anddroid-based learning media using the MIT Inventor App as a means of learning will make android more appropriate, useful, and provide ease of accessing learning for teachers and students [1]. In completely the use of android-based learning media using the MIT Inventor App in the learning process not only overcomes the limitations of the learner and classroom experience, but enables direct interaction between students and the environment,sils the uniformity of observation and can add to the basic concepts that are true, concrete, and realistic [1].

Fourth, the development of learning media using android in addition to being more precise to also be able to create active, creative and innovative learning, because undeniably, the real purpose of learning is to use the right teaching materials and vary in the learning process so as to reduce the passive attitude of the learners [12].

Fifth, within the learning process are going to be more varied methods used, not only - verbal communication through speech by teachers in order that students aren't saturated and teachers don't run out of energy, especially if the teacher teaches in each lesson [13]. So with the utilization of android-based learning media using mit inventor app is extremely helpful teacher performance and may be used as an alternate to beat the habits of scholars within the learning process.

Additional to the advantages in android-based learning media using the MIT Inventor App, there are also disadvantages in this learning medium, namely: (1) android-based learning tools use the MIT Inventor App is limited to general administration subjects basic competencies 3.10 Implementing Communication at Work and 4.10 Communication at Work, (2) Androidbased learning media using the MIT Inventor App can only be operated using android-based mobile phones, and (3) These learning media cannot besked offline completely, still required internet networks such asto access learning videos and download student worksheets

From a number of the analysis results that are done above shows that the study results of experiment class students (classes that use android-based learning media using the MIT Inventor App)scored above the control class(classes that don't use android-based learning media using the MIT Inventor App). The difference is caused by the utilization of android-based learning media are often utilized as a learning medium that supports the training process to enhance learning motivation, student performance, and student learning outcomes [14]. additionally, the utilization of android also can improve the training process that focuses on understanding the concept of scholars [15]. Androidbased learning media using the MIT Inventor App is additionally flexible which will allow students to review materials without limited time, meaning students can learn outside of lesson hours which can ultimately have 
a positive impact on students that permits for selflearning [16].

Thus it are often concluded that the utilization of android-based learning media using the MIT Inventor App generally Administration subjects is effectively utilized in the training process, because it's significant in improving the training outcomes of scholars.

\section{CONCLUSION}

The results of development in this study are Android-Based Learning Media Using MIT Inventor App in General Administration Subjects class X OTKP SMK Negeri 1 Lumajang. Based on validation or due diligence results by media experts, materials experts, and small group trials show that validity has been tested or can be said to be worthy of use as a learning medium and can improve students' learning outcomes.

In order for the resulting product to be utilized optimally in learning, researchers advise the next developer or researcher to have more creativity in designing and designing learning media to make the media more interesting and increase the user's interest in using learning media. In addition, it is necessary to add more complete material because this developed media is limited to communication materials in the workplace / office, and it would be better if the learning media could be accessed completely offline.

\section{REFERENCES}

[1] A. Ana and Y. Achdiani, "Penerapan Self Regulated Learning Berbasis Internet Untuk Meningkatkan Kemandirian Belajar Mahasiswa," INVOTEC, vol. 11, no. 1, Art. no. 1, 2015, doi: 10.17509/invotec.v11i1.4835.

[2] N. Z. A. Rahim and N. H. A. Bakar, "e-Book use by Malaysian primary school children," in 2014 Fourth International Conference on Digital Information and Communication Technology and its Applications (DICTAP), May 2014, pp. 109113, doi: 10.1109/DICTAP.2014.6821666.

[3] M. Amasha and S. Al-Omary, "Quizrevision: A Mobile Application using the Google MIT App Inventor Language Compared with LMS," International Journal of Advanced Computer Science and Applications, vol. 8, Jan. 2017, doi: 10.14569/IJACSA.2017.080641.

[4] A. Rusmiyati, "Impact Of Media QR Code To Grow The Interest Of Students Learn Sociology In Social Conflict Materials," Metafora: Education, Social Sciences and Humanities Journal, vol. 3, no. 2, Art. no. 2, Dec. 2019, doi: 10.26740/metafora.v3n2.p1-16.

[5] Sugiyono, Metode penelitian pendidikan:(pendekatan kuantitatif, kualitatif dan $R \& D)$. Alfabeta, 2008.

[6] W. R. Borg and W. R. Borg, "Educational research: an introduction / by Walter R. Borg, Gall, Meredith Damien," 1. PENDIDIKAN PENELITIAN,Educational research: an introduction / by Walter R. Borg, Gall, Meredith Damien, vol. 1983, no. 1983, pp. 1-99, 1983, doi: 1983.

[7] "Metode Penelitian Pendidikan \& Pengembangan - Prof. Dr. H. Punaji Setyosari, M.Ed - Google Books."

https://books.google.co.id/books?hl=en\&lr=\&id= SnA-

DwAAQBAJ\&oi $=$ fnd $\& p g=$ PA96\&dq $=$ metode $+p$ enelitian + pendidikan\&ots $=6 \mathrm{GHBKmCVA3 \& sig}$ $=$ EUG2H37w_rQGVF6kMrsmMLp98ec\&redir_e $\mathrm{sc}=\mathrm{y} \# \mathrm{v}=$ onepage $\& \mathrm{q}=$ metode $\% 20$ penelitian $\% 20$ pe ndidikan\&f=false (accessed Nov. 11, 2020).

[8] M. D. Gall and W. R. Borg, "Educational Research: An Introduction (7th Edition) By Meredith D. Gall, Walter R. Borg, Joyce P. Gall," EDUCATIONAL RESEARCH, p. 9.

[9] M. Jou, R. D. Tennyson, J. Wang, and S.-Y. Huang, "A study on the usability of E-books and APP in engineering courses: A case study on mechanical drawing," Computers \& Education, vol. 92-93, pp. 181-193, Jan. 2016, doi: 10.1016/j.compedu.2015.10.004.

[10] “(PDF) The Making of Mobile Learning as Learning Media Using MIT App Inventor 2 in Alternative Energy Course." https://www.researchgate.net/publication/329316 617_The_Making_of_Mobile_Learning_as_Learn ing_Media_Using_MIT_App_Inventor_2_in_Alte rnative_Energy_Course (accessed Nov. 11, 2020).

[11] H. R. Schugar, C. A. Smith, and J. T. Schugar, "Teaching With Interactive Picture E-Books in Grades K-6," The Reading Teacher, vol. 66, no. 8, pp. 615-624, 2013, doi: 10.1002/trtr.1168.

[12] M. Elyazgi, "Validating Pupils' Behaviour Intention to Use E-Book Technology in their Learning," 2018, doi: 10.14419/ijet.v7i2.29.13810.

[13] S. Suyoso and S. Nurohman, "Pengembangan Modul Elektronik Berbasis Web Sebagai Media Pembelajaran Fisika," Jurnal Kependidikan: Penelitian Inovasi Pembelajaran, vol. 44, no. 1, Art. no. 1, Jun. 2014, doi 10.21831/jk.v44i1.2193.

[14] A. Yaqin, "Pengembangan Buku Saku Digital Berbasis Android Sebagai Pendukung Bahan Ajar Pada Materi Pph Pasal 21," Jurnal Pendidikan Akuntansi (JPAK), vol. 5, no. 1, Art. no. 1, 2017, Accessed: Nov. 11, 2020. [Online]. Available: https://jurnalmahasiswa.unesa.ac.id/index.php/jpa k/article/view/17965.

[15] Lubis, "Pengembangan Media Pembelajaran Kimia Berbasis Android Untuk Meningkatkan Motivasi Belajar Dan Prestasi Kognitif Peserta Didik SMA," Jurnal Inovasi Pendidikan IPA. https://journal.uny.ac.id/index.php/jipi/article/vie w/7504 (accessed Nov. 11, 2020).

[16] L. L. Hadar, "Opportunities to learn: Mathematics textbooks and students' achievements," Studies in Educational Evaluation, vol. 55, pp. 153-166, Dec. 2017, doi: 10.1016/j.stueduc.2017.10.002. 